\title{
Sharing Practice Through Socratic Seminars
}

Sometimes, what teachers need most is to just talk with each other. The Socratic seminars were one school's way of making that happen.

\section{By Jennifer R. Mangrum}

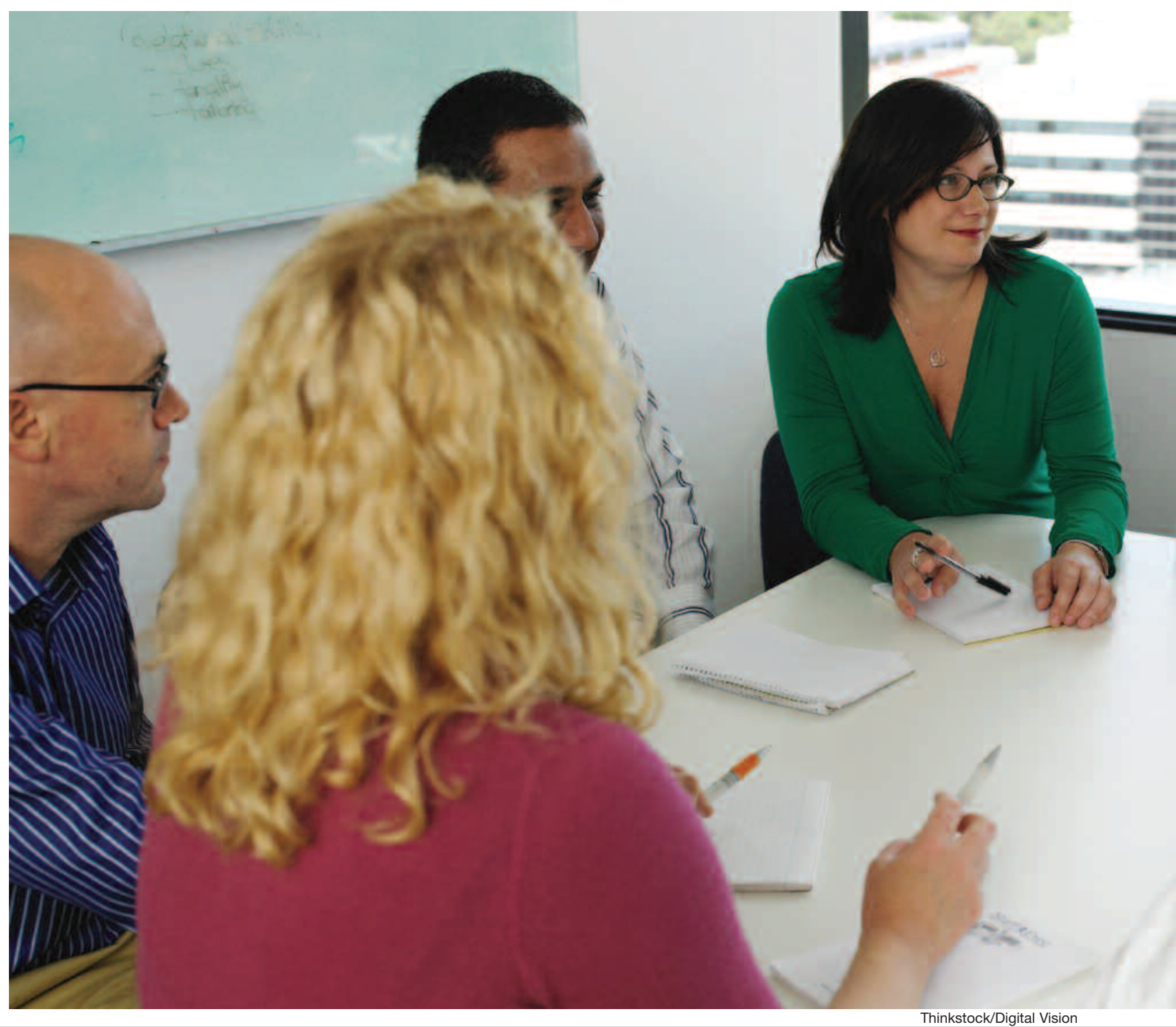


I began my teaching career across the hall from my best friend. We taught the same grade, we socialized regularly after school, and we even spent time together on the weekends. But we didn't discuss our practice. In fact, we rarely talked about teaching in any context.

I'm not sure why we behaved that way. Norms of privacy and individuality were common in the "behind closed doors" world of schools 20 years ago. Perhaps we were afraid to be vulnerable with each other, or our competitive drive discouraged us from sharing the secrets of teaching.

If schools wish to encourage and support teachers and help them work collectively instead of in isolation, then developing systems and opportunities for effective dialogue is critical. Before teachers can share openly about their practice, they must feel comfortable talking with colleagues about their beliefs, their biases, their successes, and their mistakes.
How does a school create a culture that fosters that kind of conversation?

\section{THE SCHOOL}

Smith Elementary School (a pseudonym), located in a large urban district in the southeastern United States, is a powerful example of how a faculty can achieve results through intentional dialogue about shared practice. Smith was a start-up elementary school in a high-challenge setting. The principal is white, the neighborhood is minority, and $95 \%$ of the students qualify for free or reduced-price lunch. The faculty was new to the school, though half had worked for the principal at another school.

The community around Smith had fought to have the school located on the site - and bear the name - of a historic school that had long served the community before it was lost in the district desegregation process. And they were watching closely for signs of failure.

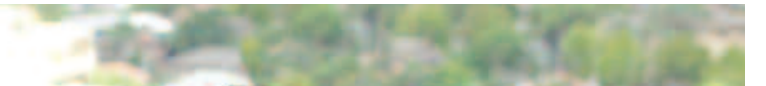 arets (2)}

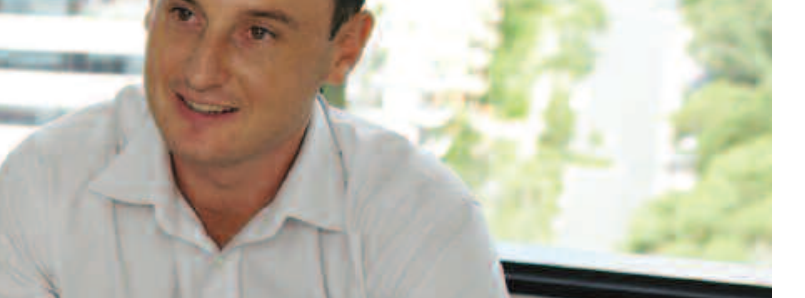
13

The principal needed to produce trust, collaboration, and cohesion in the faculty and then turn that collaboration into success for staff and students. And she needed it to happen in the first year. She chose the Socratic seminar (Roberts and Billings 1999) as the structure for building openness and trust and for establishing productive conversations that would lead to sound policies and practice in the school.

\section{PAIDEIA FACULTY SEMINARS}

The principal started the school year by establishing five mandatory "meetings" for the entire teaching faculty. These meetings were solely for the purpose of participating in faculty Socratic seminars. Socratic seminars are structured conversations about selected texts and the important ideas imbedded within them. Smith used a variety of texts, ranging from research articles to picture books. Some of the ideas and problems imbedded in the texts were collaboration, trust, racism, social justice, active learn-

JENNIFER R. MANGRUM is a visiting lecturer in the Department of Teacher Education, University of North Carolina, Greensboro. 
ing strategies, and integrating the arts. The seminars were designed to probe these ideas, allowing for a variety of interpretations.

\section{In order to develop}

$$
\text { environments that support }
$$

teacher collaboration, schools

must find ways to build trust

\author{
among faculty and systems that \\ foster teacher dialogue.
}

The structured process for planning and implementing the Socratic seminar is the key element in its success. The National Paideia Center offers materials and resources to schools (www.paideia.org) that want to adopt the seminar. The essential elements of the process are:

- Text Selection. Select texts imbedded with rich ideas important to the faculty. Texts should be open to multiple interpretations and not easily disposed of intellectually. Texts are not limited to written documents.

- Preseminar Content Activities. Faculty should interact with the text before the Socratic seminar. Typically, faculty read and respond to the text in a formal manner.

- Setting Goals. Faculty set personal behavior goals that will enhance the conversation. Examples include listening fully, allowing colleagues an equal turn to talk, and posing questions to the group. In addition, the group sets a group goal based on prior performance.

- Questions. Questions are open-ended, thoughtful, and concise. There are three types of questions asked: opening, core, and closing. Usually, one opening question is posed. This question elicits the main ideas found in the text. A minimum of three core questions follow. These questions are less open-ended because they require participants to analyze the text and support their answers based on evidence in the text. A closing question asks faculty to personalize what they've discussed and apply it to their own lives.

- Facilitation. The facilitator asks the questions, probes for deeper understanding, connects ideas, and moves the conversation forward. The facilitator can be someone from the local school or the district office.

- Assessment. After the conversation ends, each participant assesses his or her personal behavior goals. In addition, group members discuss the group's goal, how they did, and what they need to improve. One of these suggestions will become the group goal for the next Socratic seminar.

- Postseminar Content and Reflection Activities. Faculty members respond to the conversation as homework, often in written form. The postseminar activity should require reflection on the topic and some type of action.

\section{BUILDING RELATIONSHIPS}

During the seminars, teachers could get to know each other on a very personal level by opening up about important issues. In a seminar about the life of Martin Luther King Jr., several participants told stories from their own childhood during the Civil Rights Movement. In one instance, a teacher shared with the group how she misunderstood the term "colored water fountain" when she was young and how she naively expected bright colors to emerge from the fountain. She was embarrassed by her naiveté but wanted to offer to the group her stories of initiation and growing awareness.

In another example, John, a visiting international teacher from New Zealand, talked about his own childhood in a British society and how it related to the class struggles of the school's families. John grew up in a class system that labeled him as "stink" because he was poor. He shared with the group what powerful and terrible messages he received daily and how they still haunt him.

By sharing these personal stories, the Smith teachers began to see each other in different contexts and learn more about each other as people. With each personal story, the teachers developed understanding and empathy and began to form stronger relationships with colleagues.

\section{SHARING PRACTICE}

Some teachers told of their vulnerabilities professionally as well as personally. During one seminar, the guidance counselor related how one of the Smith students had contemplated suicide and had come to her for help. There was a long silence as the group processed what they heard. The counselor had provided information from her practice that reminded teachers that their students were people before they were pupils. Her story had implications for teacher practice as well. 
At the end of the seminar on using active learning strategies, the facilitator asked participants if they had had any "aha" moments in the seminar. Participants were first given time to talk in small groups. When it was time to share with the group, Darlene and two other 5 th-grade teachers admitted that, though they agree with the idea of integrating instruction and using active teaching strategies, they were struggling in their classrooms. They could barely make it to 3 p.m. each day. They felt compelled to control the classroom by administering worksheets and more direct methods of instruction. Immediately, other teachers offered support. Some praised the 5 th-grade teachers for their honesty. They also reminded the teachers that they were all making a difference and that it was going to take time.

\section{After a very demanding and challenging first school year in a highly fragile environment, no teachers requested a transfer.}

The school had created a vision but was taking baby steps to get there. At this point in the year, the teachers were weary from the demands of so many at-risk students. However, the passion and honesty in this discussion was apparent, and there was a sense of "we can do this together." In what other venue can teachers discuss their students and their work on this level? With each conversation and with each postseminar activity, teachers began to trust their colleagues.

\section{CHANGING CURRICULUM, INSTRUCTION, AND POLICY}

The faculty at Smith became intentional about making changes while creating and fostering a learning community. After each seminar, teachers implemented changes in their classrooms and throughout the school. During one seminar, the principal and teachers noted that they hadn't revisited their vision for the school since its conception. Some weren't even sure what their original vision was, although they collaborated to write it. Faculty members reread the vision statement and broke into small groups to analyze what they were doing well and what they needed to improve. They ended the session with action steps in order to better live out their vision. In this way, the conversation led to direct action at the school level.
In another seminar, teachers discussed at length their frustration with discipline. Teachers discussed the issue and created committees to address it schoolwide.

After a seminar on developing trust, teachers brainstormed various ways to engage with one another. This resulted in teachers visiting other classrooms, observing one another, eating lunch together, and even taking time in the evenings to get together for drinks and dinner at a nearby grill. The seminars brought out important issues that the entire faculty probably wouldn't have discussed otherwise.

\section{TEACHER RETENTION}

After a very demanding and challenging first school year in a highly fragile environment, no teachers requested a transfer. Teachers said having the opportunity to discuss important issues, openly share their concerns and hopes, and help bring change was critical to their job satisfaction. When asked to evaluate the Socratic seminars, teachers regarded them as "highly effective" and explained that they believed the amount of interaction between teachers was the reason.

\section{CONCLUSION}

Teachers must have opportunities to learn from and with each other. In order to develop environments that support teacher collaboration, schools must find ways to build trust among faculty and systems that foster teacher dialogue. Smith school discovered that having the entire faculty meet regularly helped them learn from each other and take responsibility for their own professional development, as well as the development of school curriculum and policy. They were able to share their practice and make changes at the classroom and school level after conversations that allowed for critical thinking and input from the entire faculty.

I was impressed that this faculty chose to stay the course and to continue to develop their practice collectively despite the daily difficulties they faced. In my own teaching, I wonder what might have happened if I had had the same opportunity to participate in meaningful faculty dialogue, to develop relationships with my peers, and to directly affect school change. My hunch is that we stayed behind closed doors because we didn't trust our colleagues, or maybe we didn't want to make ourselves vulnerable. Smith Elementary has shown that taking that risk can pay off for the entire school community.

\section{REFERENCE}

Roberts, Terry, and Laura Billings. The Paideia Classroom:

Teaching for Understanding. Larchmont, N.Y.: Eye on

Education, 1999. 
File Name and Bibliographic Information

k1004ma1.pdf

Jennifer R. Mangrum, Sharing Practice Through Socratic Seminars, Phi

Delta Kappan, Vol. 91, No. 7, April 2010, pp. 40-43.

Copyright Notice

Phi Delta Kappa International, Inc., holds copyright to this article, which may be reproduced or otherwise used only in accordance with U.S. law governing fair use. Copies of this article, in print and electronic formats, may not be made, distributed, or posted online without express permission from Phi Delta Kappa International, Inc. All rights reserved.

Note that photographs, artwork, advertising, and other elements to which Phi Delta Kappa does not hold copyright may have been removed from these pages.

All images included with this document are used with permission and may not be separated from this editoral content or used for any other purpose without the express written permission of the copyright holder.

Please fax permission requests to the attention of KAPPAN Permissions Editor at 812/339-0018 or e-mail permission requests to kappan@pdkintl.org.

For further information, contact:

Phi Delta Kappa International, Inc.

408 N. Union St.

Bloomington, Indiana 47405-3800

812/339-1156 Phone

800/766-1156 Tollfree

812/339-0018 Fax

http://www.pdkintl.org

Find more articles using PDK's Publication Archives Search at http://www.pdkintl.org/utilities/archives.htm. 